\title{
Yarrowia lipolytica yeast use for the production of biomass and lipid
}

\section{Utilização da levedura Yarrowia lipolytica para a produção de biomassa e lipídios}

\author{
Aline da Silva Delabio ${ }^{1}$, Juliana Angelo Pires ${ }^{2}$, Márcia Nalesso Costa Harder $^{3}$, Regina Teresa Rosim Monteiro ${ }^{4}$, Valter \\ Arthur $^{5}$
}

\begin{abstract}
Fuels from renewable energy are gaining space in a landscape where the unbridled use of fossil fuels endangers the world's energy future. Thus biofuels are possible substitutes for fossil fuels. The use of yeast in lipid synthesis is presented as an alternative since the lipids produced can serve as raw material for production of biodiesel. This study was conducted in order to assess the feasibility of production of lipid by Yarrowia lipolytica and a subsequent application as biodiesel. Yeasts of Yarrowia lipolytica were maintained in liquid medium, Yeast Extract Peptone Dextrose, and inoculated into medium containing agro-industrial waste (molasses and vinasse) and other available waste (urban runoff). After inoculation the medium was incubated without agitation for a period of 7; 14 and 21 days. Three bottles every seven days were taken for quantification of lipids. The length greater oil production occurred after 21 days of incubation, while greater biomass production occurred 14 days of incubation. The production of lipids was less than reported in the literature but production can be increased with the appropriate study of each nutrient composition of the culture medium. The study was conducted in laboratory scale values probably biomass and lipids are major industrial scale.
\end{abstract}

Keywords- Biomass, biodiesel, lipids, Yarrowia lipolytica, yeast.

RESUMO- Os combustíveis de energia limpa, produzidos a partir de recursos renováveis, estão ganhando espaço num cenário em que o uso desenfreado de combustíveis fósseis coloca em risco o futuro da energia no mundo. Assim, os biocombustíveis são possíveis substitutos para os combustíveis fósseis, além de serem aliados a um ambiente sustentável. A utilização de leveduras para a síntese lipídica é apresentada como uma alternativa, uma vez que os lípidos produzidos podem servir como matéria-prima para a produção de biodiesel. Este estudo foi realizado a fim de avaliar a viabilidade da produção de lipídios por Yarrowia lipolytica e uma posterior aplicação como biodiesel. Leveduras de linhagem Yarrowia lipolytica foram mantidas em meio líquido, Extrato de Levedura, Peptona, Glicose, e inoculadas em meio contendo resíduos agroindustriais (melaço e vinhaça) e outros resíduos disponíveis (esgoto urbano). Após a inoculação, o meio foi incubado sem agitação durante um período de 7; 14 e 21 dias. Três amostras a cada sete dias foram levadas para a quantificação de lipídios. A maior produção de óleo ocorreu no $21^{\circ}$ dia e a maior produção de biomassa ocorreu no dia $14^{\circ}$ dia. A produção de lipídios foi menor do que a relatada na literatura, mas pode ser melhorada com o estudo adequado das proporções de cada nutriente. Além disso, todos os estudos baseiam-se em escala laboratorial, em escala industrial provavelmente ocorrerá o aumento da produção de biomassa e a síntese de lipídios.

Palavras-Chave- Biomassa, biodiesel, lipídios, Yarrowia lipolytica, levedura.

\footnotetext{
*Autor para correspondência

Recebido para publicação em 15/01/2015; aprovado em 25/02/2015

${ }^{1}$ Centro de Energia Nuclear na Agricultura/CENA/USP. Laboratório de Radiobiologia e Ambiente. E-mail: adelabio@cena.usp.br

${ }^{2}$ Faculdade de Tecnologia Dep. "Roque Trevisan"- Fatec Piracicaba. E-mail: japires@ymail.com

${ }^{3}$ Prof. Dr ${ }^{a}$ Coordenadora do curso de Tecnologia em Alimentos na Fatec/Piracicaba. E-mail: marcia.harder@fatec.sp.gov.br

${ }^{4}$ Prof. Dr ${ }^{\mathrm{a}}$ do Laboratório de Ecologia Aplicada- CENA/USP. E-mail: monteiro@ cena.usp.br

${ }^{5}$ Prof. Dr. no Laboratório de Radiobiologia e Ambiente- CENA/USP. E-mail: arthur@cena.usp.br
} 


\section{INTRODUCTION}

The use of yeast is related to various sectors of the agricultural industry such as production of ethyl alcohol; beverage; bakery; food enrichment for humans and animals and pro biotics (VICTORELLI, 2008).

Yarrowia lipolytica is a yeast strictly aerobic and has the ability to generating products of great industrial interest, such as lipases, citric acid and proteins (AMARAL, 2007).

Currently the most important use of this yeast is lipase production because of the wide applicability of this product. Depending on their catalytic properties may be employed in the detergent industry; in the oil-processing industry; in pharmaceuticals; in paper and pulp industry; the production of biodiesel and industrial waste treatment (AMARAL, 2007).

For the production of lipids yeasts are grown in media to provide optimal conditions for their growth and development (LIMA e SATO, 2001).

For a candidate microorganism is favorable to commercial interests must present $20-25 \%$ of their biomass into lipids (RATLEDGE, 1996).

Yeasts capable of producing lipids normally accumulate little oil. The production of fatty material becomes significant when nutrient sources decreases especially when the nitrogen content reaches the threshold requirements. The carbon source is always required in large quantity (LIMA e SATO, 2001).

Upon the foregoing the present work aimed to evaluate the production of biomass and lipids by Yarrowia lipolytica from the agroindustry waste and other waste available and these lipids may in the future be converted into biodiesel.

\section{MATERIALS AND METHODS}

\section{Microorganisms}

We used yeasts Yarrowia lipolytica donated by the Department of Biochemistry and Microbiology UNESP/Rio Claro Campus.

The cultures were maintained in liquid medium (the preservation medium) composed by g. $\mathrm{L}^{-1}: 10 \mathrm{~g}$ yeast extract; $20 \mathrm{~g}$ peptone; $20 \mathrm{~g}$ glucose; dissolved in water. After adjusting the $\mathrm{pH}$ to 6.5 ; and then the medium was autoclaved at $121^{\circ} \mathrm{C}$ and $1 \mathrm{~atm}$ pressure for $20 \mathrm{~min}$. Once a week the yeasts were renewed (BARNETT, PAYNE e YARROW, 1983).

\section{Preparation Method of Cultivation}

Were used for the preparation of the medium: sewage; sugarcane honey $4 \%$ and stillage $20 \mathrm{ml}$ of each solution in nine Erlenmeyer flasks.

Table 1: Values of glass bottles before lyophilization

\begin{tabular}{ccc}
\hline & Weight of glass bottles before lyophilization & \\
\hline For the $\mathbf{7}^{\text {th }}$ day: & For the $\mathbf{1 4}^{\text {th }}$ day: & For the 21 $^{\text {st }}$ day: \\
13,4735 & 12,7317 & 12,9971 \\
13,3828 & 13,3121 & 12,9566 \\
13,4707 & 13,1174 & 13,4881 \\
13,0061 & 13,3261 & 13,1338 \\
\hline
\end{tabular}

Were mixed in a 2 liter becker: $200 \mathrm{ml}$ of sewage; $200 \mathrm{ml}$ of vinasse, $8 \mathrm{ml}$ of sugarcane honey $+192 \mathrm{ml}$ of distilled water (4\% sugarcane honey). Adapted from CAZETTA e

After the preparation has been done through adjusting the $\mathrm{pH}$ to 6.5 with $0.1 \mathrm{~N} \mathrm{NaOH}$ and/or $1 \mathrm{~N}$. After the adjustment, $60 \mathrm{ml}$ of medium was distributed into Erlenmeyer flasks and autoclaved at $121^{\circ} \mathrm{C}$ for $15 \mathrm{~min}$.

\section{Growth Medium of Inoculum}

After autoclaving the bottles were placed in Erlenmeyer flasks flow chamber with uv light on for protection against pathogens. Then with the light off the yeast was inoculated and willing without agitation. The incubation period was 7; 14 and 21 days (CAZETTA e CELLIGOI, 2005).

\section{Determination of Biomass}

To determine the dry mass were used three Erlenmeyer flasks for each period (replication) and these being placed in Falcon tubes for centrifugation and precipitation of the biomass. The biomass obtained was transferred to glass vials with screw cap and frozen at $-18^{\circ} \mathrm{C}$. The biomass obtained by centrifugation was measured gravimetrically after the lyophilization (VICTORELLI, 2008).

\section{Lyophilization}

The glass vials were frozen at $-18^{\circ} \mathrm{C}$ and was driven without the cover to the lyophilizer which technique is used to sublimate the ice passing from solid to gas to maintain the yeast characteristics.

The biomass was calculated by difference in weight of glass bottles before and after lyophilization (VICTORELLI, 2008).

\section{Determination of the lipid content}

The extraction of lipids was performed by AlgaGeo Company, located in São Paulo, SP, Brazil. The yield was calculated using the formula: oil mass $\mathrm{x} 100 /$ biomass (CARVALHO, 1994).

\section{RESULTS AND DISCUSSION}

The results calculated for the biomass before and after lyophilization, are shown in Tables 1 and 2 .

Table 3 shows the values of the biomass obtained by the sample and the oil mass and yield.

The incubation period with greater biomass production occurred on day 14 and the period with higher lipid yields came on day 21 as shown Graphic 1. CELLIGOI (2005). 
Table 2: Values of glass bottles after lyophilization

\begin{tabular}{ccc}
\hline & Weight of glass bottles after lyophilization: & \\
\hline For the $\mathbf{7}^{\text {th }}$ day: & For the $\mathbf{1 4}^{\text {th }}$ day: & ${\text { For the } \mathbf{2 1}^{\text {st }} \text { day: }}^{\text {(13, }}$ \\
13,7884 & 12,9277 & 13,1349 \\
13,5692 & 13,4798 & 13,7104 \\
13,6902 & 13,4433 & 13,3080 \\
13,1946 & 13,6060 & 1390 \\
\hline
\end{tabular}

Table 3: Values of dry pasta, pasta and oil yield Yarrowia lipolytica grown in medium composed

\begin{tabular}{ccccc}
\hline Samples & Incubation & Biomass $\left(\mathbf{g l}^{\mathbf{1}}\right)$ & ${\text { Oil Mass }\left(\mathbf{g l} \mathbf{-}^{\mathbf{1}}\right)}$ & Yield $(\%)$ \\
\hline 01 & $7^{\circ}$ Day & $0.2273^{\mathrm{A}^{*}} \pm 0,060^{* *}$ & $0.0074^{\mathrm{A}^{*}} \pm 0,002^{* *}$ & $3.2759^{\mathrm{B}} \pm 0,219^{* *}$ \\
02 & $14^{\circ}$ Day & $0.2423^{\mathrm{A}^{*}} \pm 0,073^{* *}$ & $0.0080^{\mathrm{A}^{*}} \pm 0,001^{* *}$ & $3.4990^{\mathrm{B} *} \pm 0,744^{* *}$ \\
03 & $21^{\circ}$ Day & $0.1634^{\mathrm{A}^{*}} \pm 0,044^{* *}$ & $0.0087^{\mathrm{A}^{*}} \pm 0,002^{* *}$ & $5.4345^{\mathrm{A}^{*}} \pm 1,320^{* *}$ \\
\hline
\end{tabular}

*Sample of the same letter in column do not differ significantly at $5 \%$ for the Tukey test.

***Mean values of triplicate samples \pm standard deviation.

Figura 1. Relationship of yield for biomas

\section{Biomass Relationship/Yield}

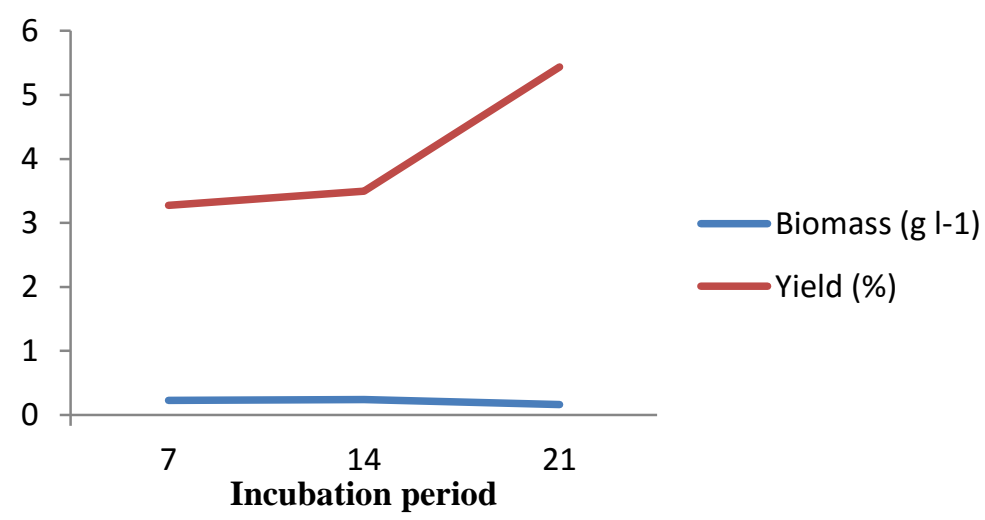

The lipid yield was lower than 20-25\% showing that a level below that recommended by Ratledge (1996) to consider a lipolytic microorganism (Table 1), however lipids are the result of the secondary metabolism has the possibility of improves yield with studies that proper proportions of each nutrient. Another factor to be taken into account is that the medium is less than one half synthetic medium and values must be recalculated to known what is the cost-effective.

For the three incubation periods $(7,14,21)$ there were no statistical differences in biomass and lipid extracted, however, as the percentage of total lipids, (result of lipid extracted divided by biomass and multiplied by 100) was statistical difference between the $21^{\text {th }}$ day (higher yield) than the incubation periods.

Furthermore this study was conducted in laboratory scale. On an industrial scale the results can be more significant since space and environmental conditions influence an increase in production and consequently a higher lipid yields.

\section{CONCLUSION}

According to the theoretical research and developed the yeast Yarrowia lipolytica has the ability to lipid synthesis which may be improved with the appropriateness of the medium for yeast.

The study of the incubation period pointed out that it is possible to obtain a larger amount of oil even during periods with lower biomass production.
Regarding the medium composition, recall, residues that are inexpensive; easily available; which can be reused in the culture medium for the growth of yeasts.

To recognize the quality of lipids extracted from the yeast Yarrowia lipolytica is just made the oil acidityl. This alone will provide parameters that prove the efficiency of its conversion into biodiesel.

\section{REFERÊNCIAS BIBLIOGRÁFICAS}

AMARAL, P. F. F. Production of Yarrowia lipolytica lipase in multiphase bioreactor. 2007, 220p. Thesis (Doctor of Science) - Federal University of Rio de Janeiro, 2007.

BARNETT, J. A.; PAYNE, R.W.; YARROW, D. Yeasts: characteristics and identification. Cambridge University Press, 811p. 1983.

CARVALHO, P. O. Production of gamma linolenic acid by a newly isolated strain of Mucor SP and study of fermentation conditions, 1994, p. Dissertation (Master in Food Sciences) Faculty of Food Engineering, UNICAMP, Campinas, 1994.

CAZETTA, M.; CELLIGOI, M. Utilization of molasses and vinasse from cane sugar as a substrate for the production of biomass and lipid protein by yeasts and bacteria. London, v. 26, n. 2, p. 105-112, Jul. / Dec. 2005. 
LIMA, U. A., SATO, S. Lipid production by microorganisms. In: Industrial Biotechnology. 2nd. Ed São Paulo: Blucher, 2001. Chapter 16, p. 447-463, 2001.

RATLEDGE, C. Microorganisms for lipids. In: Meesters, P. A.; HUIJBERTS, G. N. High cell-density cultivation of the lipid accumulating yeast Cryptococcus curvatus using glycerol as a carbon source. Applied Microbiology Biotechnology, v.45, n.5, p.575-579, 1996.

VICTORELLI, R. Selection of yeast producing lipids. Work Completion of course 64p. Biosciences Institute, Rio Claro, UNESP 2008. 